\title{
Ernest Hart and the social thrust of Victorian medicine
}

\author{
George K Behlmer
}

The British Medical fournal emerged as a powerful shaper of public opinion largely through its campaigns against perceived evil during the last third of the nineteenth century. There is no doubt that the journal's care in publicising debates on the aetiology of disease, reporting advances in medical diagnosis, and documenting refinements in surgical technique made it a vital asset to the general practitioner who, even a century ago, was already overwhelmed with the sheer volume of specialised medical literature. But the journal's rise to prominence as an advocate of what Victorians loosely termed "social progress" was especially remarkable, and for two reasons. Firstly, its transformation into an organ preoccupied with improving Britain's quality of life took place very rapidly. Secondly, the energy behind this transformation was supplied by one man, Ernest Hart, editor of the journal from 1866-98.

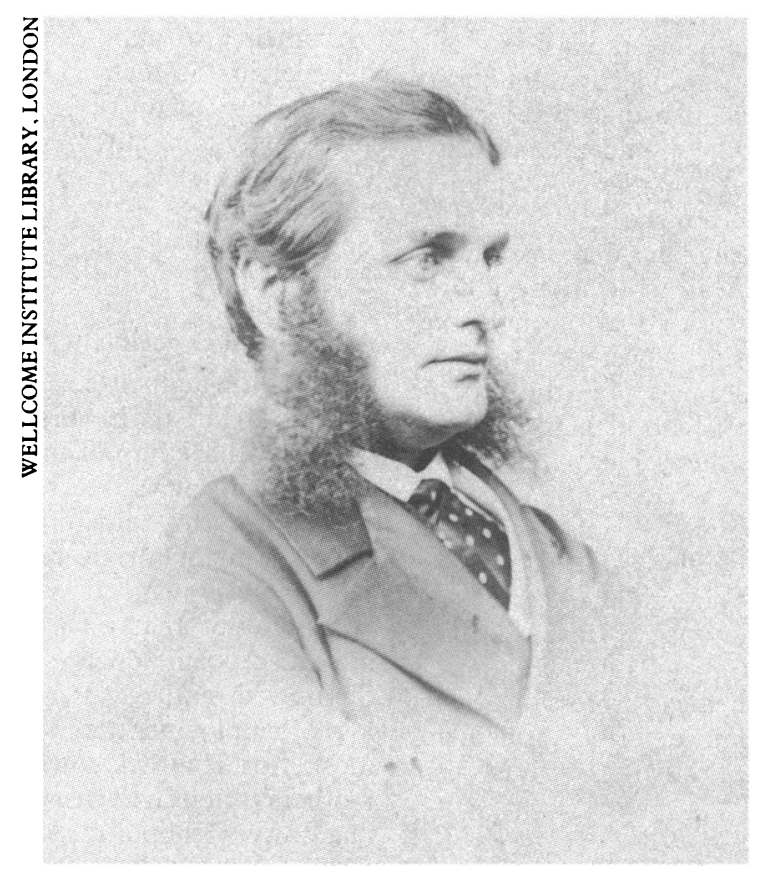

Department of History DP-20, University of Washington, Seattle, Washington 98195, United States George K Behlmer, PHD, associate professor

BrMed f 1990;301:711-3 ability, and impatience would remain Hart's hallmarks throughout his long tenure as crusader-in-chief of the medical profession.

This role began to emerge before his association with the journal. From 1863 to 1866 , in addition to his surgical and administrative duties at St Mary's, Hart served as a literary assistant with the Lancet. It was in this capacity that he launched a medical investigation into the care of the poor in London workhouses. As the Lancet's editorial of April 1865 explained, "it is necessary that public opinion should be fully enlightened and deliberately directed" to reform a system that shamefully neglected the sick poor. ${ }^{4}$ This formulation - almost certainly Hart's own - captured the essence of his bent as a reformer: it was not enough to expose a social evil nor to trust in the power of popular indignation, once aroused. Rather, medical science was obliged to batter down the doors of ignorance, apathy, and greed. Moreover, in his subsequent depiction of poor law infirmaries as England's "state hospitals," Hart was giving voice to a view of social reform that placed great weight on the state as prime guardian of the public welfare. In an age still deeply suspicious of collectivist solutions for social problems Hart was insisting that the health of the nation demanded a rethinking of the laissez faire precepts that dominated Victorian notions of good government.

\section{Hard fought battles}

In pursuit of what he saw as public safety the man who became editor of the $B M \mathcal{F}$ in 1866 sometimes rode roughshod over individual rights. Hart's passionate intolerance of half measures was nowhere plainer than in connection with the debate over control of venereal disease. In 1864 the journal had assailed a plan to combat syphilis in garrison towns and naval ports by empowering local police to detain women on the mere suspicion of being infected. According to the journal, this plan, embraced in the Contagious Diseases Bill, was the most "iniquitous interference with the liberty of the subject ... proposed in the House of Commons .. . since the days of Charles I." Once Hart assumed its editorship, however, the journal performed an about face, lining up squarely behind those who advocated extending the act to civilian centres. Hart, in fact, was one of the key figures in persuading parliament to enlarge the scope of the 1864 law, a campaign that met with partial success five years later. Whether or not Hart deserved to be labelled a misogynist for refusing to acknowledge the double standard inherent in the legislation of 1864,1866 , and $1869,{ }^{7}$ he obviously saw the early feminist opposition to the acts as regressive, for in his view, at least, the imperatives of public health were being sabotaged by "the disturbing vigilance of certain ladies who constitute themselves the advocates of liberty of the baser members of their sex." 8

With the repeal of the Contagious Diseases Acts in $1886 \mathrm{Hart}$ and his medical allies lost a bitterly fought contest. But more often than not the editor won his battles. Hart must have been pleased, for example, that g rapid and irrevocable conclusions. Afte Hart had been a wunderkind: selected captain of his school at 13, admitted to the Royal College of Surgeons at 21, and appointed Dean of the medical school at St Mary's Hospital by the age of $29 .^{3}$ Ambition, 


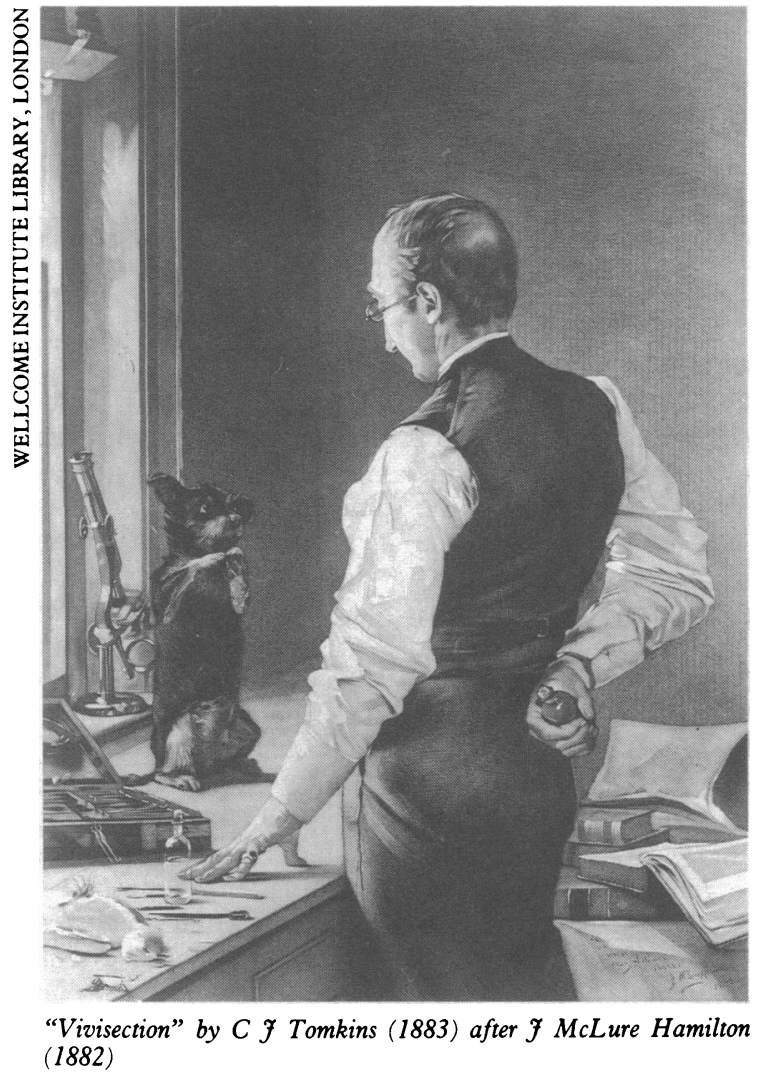

the foes of experimentation on living animals regarded him as the medical profession's "chief wire-puller." Predictably, the question of whether the advancement of medicine through vivisection should take priority over animal rights gave Hart no reason to pause. Science was not for the squeamish. In 1879 three medical men who had participated in a demonstration, sponsored by the British Medical Association, of how epilepsy could be induced in a dog through the intravenous injection of absinthe were charged at Norwich with cruelty to an animal. That the experiment was decidedly crude in conception mattered little to Hart. What did matter was the "lamentable display of fanatical ignorance" by the local bench in allowing the prosecution. ${ }^{10}$ Even though several prominent doctors were opposed to vivisection, and despite the fact that most physicians had no firsthand experience with operating on living animals, Hart's heated editorials succeeded in portraying antivivisectionist legislation as a slur on the medical profession. Such ad hominen argument not only deterred parliament from enacting a more restrictive law but also

Muck-and brass; Widnes, 1895

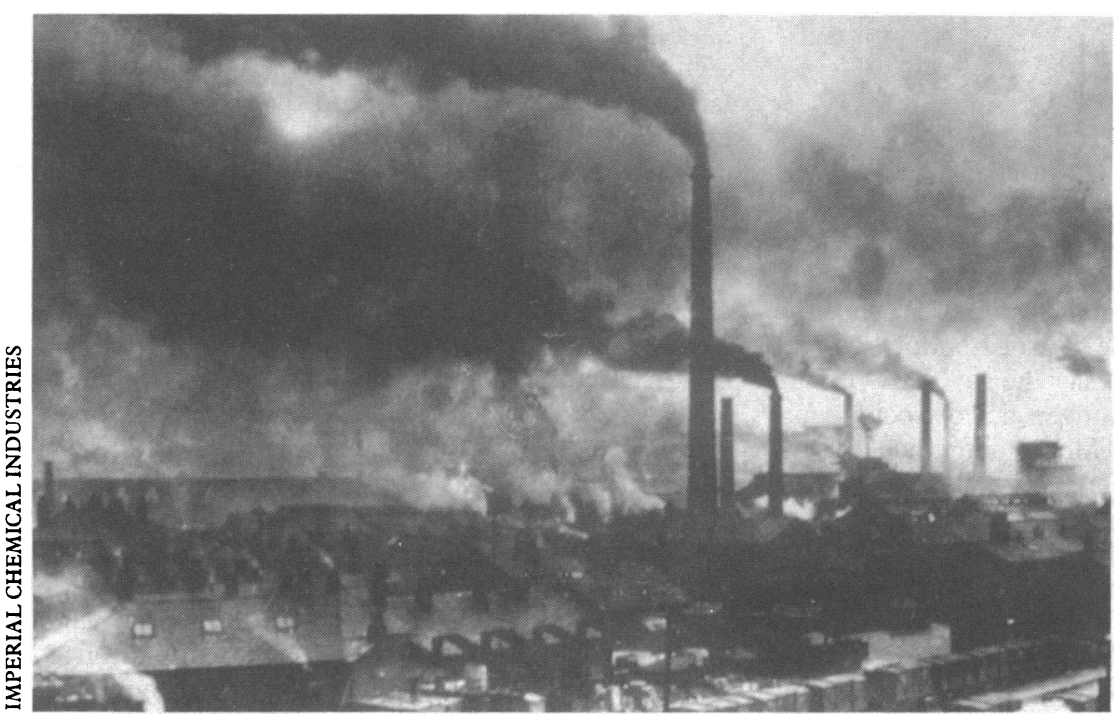

encouraged newspapers and periodicals to question the motivation of antivivisectionists. ${ }^{11}$

\section{Environmental awareness}

Although Ernest Hart today seems typically Victorian in his self righteous devotion to duty (he could not have been more aptly named), the duties he assumed often seem strikingly modern. Few public figures of the late nineteenth century, for instance, were more alert to the hazards of a polluted urban environment. Although born and raised in London, Hart never grew inured to the foul water, food, and air that so many residents of Europe's largest city were prepared to accept. From 1865, when he took part in the investigation of a mysterious outbreak of cholera at Theydon Bois, through the mid-1890s, when he ridiculed the old quarantine system as a means of containing epidemic disease, Hart missed few opportunities to emphasise the close relation between a pure water supply and improved public health. ${ }^{12}$ Similarly, his careful case studies linking zymotic diseaseprincipally typhoid fever, scarlatina, and diphtheriawith tainted milk spurred medical officers of health to take action on a local level two decades before municipal milk "depots" were first established in England..$^{13}$ With regard to the atmospheric pollution that plagued late nineteenth century London, Hart's environmental activism seems unusually prescient. The lethal "fog" that may have killed as many as $\mathbf{4 0 0 0}$ Londoners in mid-December $1952^{1415}$ finally pushed parliament to impose severe restrictions on coal burning in the metropolis. But more than 70 years earlier Hart had decried the lack of an efficient sanitary authority to monitor smoke emission in greater London-smoke that in February 1880 caused a human "slaughter" worse than at any time before or since. ${ }^{16}$

\section{An unusual experiment}

It was a slaughter of a different kind, however, that launched Hart on his first and perhaps most famous crusade while editor of the journal. Between 1858 and 1865 British newspapers and magazines gave special attention to the crime of infanticide, a barbarity that most commentators feared was on the rise. Whether this fear was justified is questionable; but there can be no doubt that as a result of the mid-Victorian infanticide panic doctors began to heed the plight of the unwed mother. ${ }^{17}$ Facing social censure, the likely loss of employment, and a legal system that thwarted most efforts to track down the men responsible, single mothers often had reason to wish for an end to maternity. Killing the baby was the most drastic response; "farming" it out to professional foster parents was a less desperate act, though frequently no less lethal for the child. In 1865 the trial of Charlotte Winsor, a Devonshire entrepreneur who gladly smothered illegitimate infants for a fee, created a short term sensation throughout Britain and a more long lasting impression on several London doctors. ${ }^{18}$ Of these, two members of the Harveian Society, J B Curgenven and Ernest Hart, vowed to destroy the practice of professional adoption. By arranging deputations to the Home Office and by delivering public speeches on the subject Curgenven did much to keep the issue alive. It was Hart, though, who gave substance to hazy suspicions of foul play when in early 1868 he hit on the idea of simulating an "adoption" (technically adoption in the sense of the transfer of parental rights and liabilities was unknown under English common law until 1926).

Working with Dr Alfred Wiltshire, Hart placed an advertisement in the Clerkenwell News requesting a 
nurse to assume responsibility for a child. Within a week they had received 333 replies to their offer of a $£ 5$ premium. Although only a few of the respondents volunteered their home addresses, it was possible to locate a majority of them because most who listed post office addresses consented to a rendezvous. Under the guise of a distressed father burdened by a bastard child Dr Wiltshire visited the homes of as many respondents as possible. The outcome of the inquiries, as Hart put it, "was to establish beyond doubt ... that many of these women carried on the business [of adoption] with a deliberate knowledge that the children would die very quickly and... with a deliberate intention that they should die." 19

Between 25 January and 28 March in 1868 the journal carried five leading articles based on Hart's experiment. The editor prefaced these reports with a stinging critique of official inaction, declaring, "but for the surprising apathy which our governmental powers display... we should have hesitated to undertake singlehanded the task of ... exposing the details of the system of baby-farming and baby-murder." ${ }^{20}$ Despite the furore that Hart's exposé ignited, the government of the day refused to sponsor remedial legislation or to mount an official inquiry. It required yet another grotesque revelation - that of two Brixton sisters who were in the business of starving and poisoning their illegitimate charges - to summon up a new pressure group composed this time of prominent laymen as well as doctors - the Infant Life Protection Society. Although he continued to argue that state inspection of farmed out children was an "eminently medical" issue, ${ }^{21}$ Hart threw himself into lobbying for the society. The 1872 Infant Life Protection Act was the ultimate fruit of that effort-fruit that tasted bittersweet to those who had worked so long on behalf of the newly born. The act itself was disappointingly narrow

"Sick Child" by Edvard Munch (1885-6)

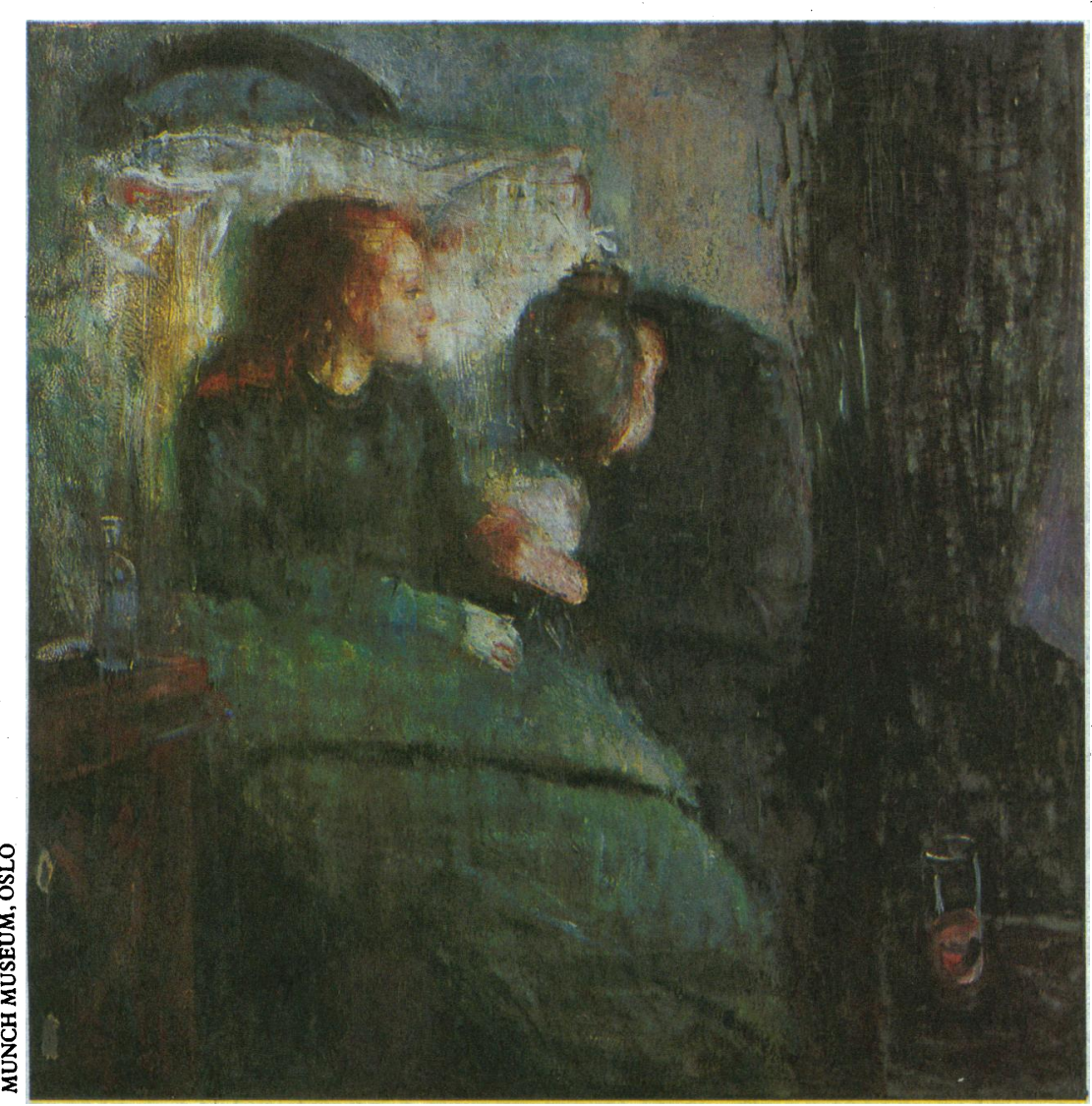

$1880 \mathrm{~s}$

- 1882: Robert Koch discovers the tubercle bacillus

- 1883: Louis Pasteur vaccinates against anthrax

accepted single infants for cash payment. But in a larger sense the climate of concern that Hart and his allies had created made it possible to liberalise the bastardy laws as well as to improve the registration of births. ${ }^{22}$ Never again would the unmarried mother be quite so helpless or the illegitimate child quite so vulnerable.

\section{Educational weapon}

Ernest Hart's key role in the mid-Victorian campaign to safeguard infant life may be seen as a microcosm of his career. Utterly convinced that nothing short of state intervention would work to protect the Queen's smallest subjects, Hart spared no effort to persuade firstly his medical peers and later the reading public that new law was essential. If Hart's reforming zeal appears today as verging on the maniacal we should consider the obstacles he faced. Chief among these was a reluctance to accept unpleasant realities. It took repeated assaults on public sensitivity to drive home the fact that some adults had a cold-blooded disregard for infant life. Interestingly, much the same barrier faced British and American doctors who began in the 1960 s to describe a "battered baby syndrome." Firstly, orthopaedic surgeons and paediatricians and, later, lay persons had to accept the grim truth "that not all parents, even if warned, are safe custodians." ${ }^{23}$ A century earlier Hart had grasped the point that at the core of meaningful social reform lay re-education, and it was above all as an educational weapon that he wielded the $B M \mathcal{F}$ for more than three decades.

1 Behlmer G. Child abuse and moral reform in England 1870-1908. Stanford, California: Stanford University Press, 1982:28.

2 Lee S, ed. Dictionary of national biography. First supplement. Vol 2. London: Smith, Elder, 1901:396-7.

3 Holmes T. In memory of Ernest Hart. Br Med f 1898;i:176.

4 Anonymous. "The Lancet" commission to inquire into the state of workhouse hospitals. Lancet 1865; i:410.

5 Hart E. The condition of our state hospitals. Fortnightly Review 1865;3: 218-21.

6 Anonymous. Legislation for prostitution. Br Med f 1864;ii:42-3.

Walkowitz JR. Prostitution and Victorian society. Cambridge: Cambridge University Press, 1980:81.

8 Anonymous. Protection of infant life. Br Med f 1883;i:69-70.

9 French R. Antivivisection and medical science in Victorian society. Princeton, New Jersey: Princeton University Press, 1975:130-2.

10 Anonymous. M Magnan's experiments. Br Med f 1874;ii:828-9.

11 French R. Antivivisection and medical science in Victorian society. Princeton, New Jersey: Princeton University Press, 1975:130-2.

12 Brand JL. Doctors and the state. Baltimore: Johns Hopkins University Press, 1965:45.

13 Home Office. Resolutions passed at the Infantile Monality Conference, London 1906. London: Public Record Office, Home Office papers, H045/10335/ 138532.

14 Anonymous. The toll of fog. $B r$ Med f 1953; i:321.

14 Anonymous. The toll of fog. Br Med f 1953;i:321.

16 Anonymous. Fog fatality in London. Br Med $\mathcal{J} 1880 ;$; :254.

17 Behlmer G. Deadly motherhood: infanticide and medical opinion in midVictorian England. Foumal of the History of Medicine and Allied Sciences 1979;34:403-27.

18 Anonymous. Infanticide. The Times 1865 August 2:9.

19 Select Committee on Infant Life Protection. Questions 18-26, 30, 44. Parliamentary Papers 1871; VII.

20 Anonymous. Baby-farming and child-murder. $\mathrm{Br} \mathrm{Med} \mathcal{f}$ 1868;i:75.

21 Anonymous. Baby-farming. Br Med f 1870;i:443, 451 .

22 Anonymous. Unlawful disposal of infants. Br Med f 1873;i:379.

23 Griffiths DL, Moynihan FJ. Multiple epiphysical injuries in babies. Br Med $f$ 1963:ii:1558-61. 